\title{
HISTORY OF SCIENCE
}

\section{DOI: 10.32703/2415-7422-2019-9-1(14)-64-76}

UDC 378.09

Bandus Viacheslav

Odessa National Polytechnic University

1, Shevchenko avenue, Odessa, Ukraine, 65044

e-mail: slava-bandus@mail.ru

https://orcid.org/0000-0003-0387-9068

\section{The textbook "Parts of Machines" by V. O. Dobrovolsky and its importance for the development of higher technical education in Ukraine}

Abstract. The article describes the activities of the famous Ukrainian researcher, Doctor of Technical Sciences, Professor of the Odessa Polytechnic Institute Victor Opanasovich Dobrovolsky on the preparation of seven editions of the textbook «Parts of Machines». At the present stage of development of the history of science and technology, a comprehensive analysis of the scientific activities of V. O. Dobrovolsky, in the field of general engineering is extremely limited, and coverage of its role in the organization and development of higher technical education in Ukraine is practically absent. The scientist was one of the first who responded to the lack of a full-fledged manual on the discipline "Parts of Machines» for higher education and devoted most of his work at the Odessa Polytechnic Institute to solving this issue. The evolution of the textbook, from the publication of scientists in 1926 the first edition "Lecture notes» to the last, the seventh, personal edition of the «Parts of Machines» 1954 has been analyzed. The main directions and priorities that were identifying by the researcher in each of the publications for the preparation of students and technician have been defined. The place of personal scientific achievements, developments, inventions of $V$. O. Dobrovolsky and his colleagues and students in the preparation of materials of the textbook, conformity of the given information to the courses' programs and all sorts of recommendations from the Ministry of Education and a wide stake of scientists with whom Viktor Opanasovich collaborated have been considered. The correspondence of textbooks to modern achievements of science and technology and the scientist's constant attention to new home and foreign developments and inventions have been described. The common features and differences in the structure of textbook, causes of reductions, additions, and the emergence of new sections, in accordance with the tasks, which were faced V. O. Dobrovolsky in different periods of its activities have been established. The great popularity and widespread use of the textbook by the majority of higher 
technical institutions throughout the USSR which was a consequence of the general availability and in-depth processing of the stated theoretical and practical material, its relevance and compliance with the challenges of time have been noted.

Keywords: V. O. Dobrovolsky; professor; ONPU; general engineering; transmission

\section{Introduction}

The rapid development of world machine-building, increasing its technology and miniaturization led to the emergence of a number of specialized scientific disciplines necessary for the training of engineers and designers. Under the influence of these processes in the second half of the nineteenth century, the division of the science of mechanical engineering took place in a number of fundamental directions: technical mechanics, applied mechanics, resistance to materials and parts of machines. Before the discipline of the machine parts, the task of studying modern methods of calculation and the basics of the design of individual details, which was the basis of the creation of any complex mechanism, and transformed it into the theoretical basis of machine building and engineering design, arose. The first textbook entitled "Parts of Machines" on the territory of the Russian Empire in 1881 became the work of the outstanding scientist, founder of higher technical education in Ukraine V. L. Kirpichova, whose ideas and undertakings, found further development in the writings of other scholars: P. K. Khudyakova, A. I. Sidorova, V. E. Thira, A. N. Rogovsky, I. I. Bobarikova and others (Ivanov \& Finogenov, 2008, p. 5).

Among scientists, whose scientific work was of fundamental importance for the development and establishment of domestic and world machine-building in the first half and mid-twentieth century. An important place is occupied by the figure of Victor Opanasovich Dobrovolsky (1884-1963). The research activity of the prominent Ukrainian scientist, doctor of technical sciences, professor of the Odessa Polytechnic Institute, whose authorship covers more than 160 scientific works on the design of machines and transmissions, materials science, which greatly contributed to the revival of scientific and technological progress of the country, impresses with its versatility and diversity. However, the most significant part of his scientific heritage is the multiple editions of the textbook "Parts of Machines", which became a solid ground for the training of engineers around the world. The coverage of the role and place of a scientist for the development of domestic engineering by modern Ukrainian historiography is extremely limited and consists of works of a general biographical nature issued by a number of OPI figures, among which it is particularly worth noting the works of V.S. Gusarev (Gusarev, 2015), K. I. Zablonsky (Zablonskij, 1998) and a bibliographic index published by the staff of the Scientific and Technical Library of ONPU (Gnatjuk, Islamgulova \& Jakovleva, 2008). The lack of scientific works that would provide a comprehensive assessment of the scientific heritage of Victor Opanasovich, based on a general analysis of his works, only increases the relevance of the research topic. The purpose of this work is to highlight 
and analyze the author's textbook of the scientist "Parts of Machines" and its importance for the development of a high technical school in Ukraine.

\section{Research methods}

The basis of this work is the general scientific principles of research, such as objectivity, scientific, historicism, systemic, complexity. Widespread use of analysis and comparative-historical methods made it possible to identify and trace the relationship between different editions of the textbook of the scientist. With the help of the systemic method, each separate manual appeared as a complex system of interconnected elements and allowed to reveal a number of regularities that were the basic elements for the discipline "Parts of machines" from the point of V. O. Dobrovolsky. Also, when writing the work, it was applied: historical, problemchronological, historiographical and biographical methods.

\section{Results and discussion}

Determining role in the formation of V.O. Dobrovolsky as an engineer, mechanician, and later a scientist of general engineering determined the studies in 1902-1908 at the Faculty of Mechanics and Technology of the Kharkov Institute of Technology (Archive ONPU, p. 3). In Kharkov, he met Professor of the Institute Vadim Erastovich Tyr, the author of the textbook "Parts of Machines" in 1907 (Electrotechnical Herald, 1926), whose professionalism, awareness and scientific interests were of great importance for the preparation of Viktor Opanasovich. Significantly contributed to the expansion of the scientific outlook of the scientist during his studies in KhTI and in subsequent years acquaintance with the works of A. I. Sidorov and P. K. Khudyakov the problems of designing and designing machines that were one of the most advanced in the Russian Empire (Dobrovol'skij, 1954, p. 11).

The activity of teaching the discipline "Parts of Machines" a scientist began in 1918 in the newly founded Odessa Polytechnic Institute and at the Evening Workers' College (Gnatjuk, Islamgulova \& Jakovleva, 2008, p. 6). Immediately with the beginning of the course, V. O. Dobrovolsky faced a number of serious problems: the low level of students' training, which was considerably worse in connection with the First World War and the Civil War in the territory of the Russian Empire, the weak link of the curriculum with a practical component machine building, the lack of a clear and comprehensive manual for the training of engineers and designers, which fully meets the modern challenges facing science. To fill the need for higher education in a new and compact comprehensive textbook that covered new achievements in science, took into account changes in the normalization and standardization of parts, and met a number of prominent scholars with the task and program of the course. In 1925 and 1926 A. I. Sidorov published in two parts a manual entitled "Course of Machine Parts," in 1926, P. K. Khudyakov published a textbook "Details of Machines," I. I. Bobarikov prepared in 1926 work "Parts of Machines" (Dobrovol'skij, 1954, p. 12). 
V. O. Dobrovolsky tried to solve the problem with the lack of academic literature on discipline. The great practical experience in the field of production, scientific work in various fields of engineering and teaching during the 1918-1926 years. The disciplines "Parts of Machines" provided Viktor Afanasovich with the necessary foundation for the publication of the "Abstract for the course "Parts of Machines" in 1926 (Gnatjuk, Islamgulova \& Jakovleva, 2008, p. 23). The main provisions laid down by the scientist in the pages of his own lecture notes relate to the availability, systematization and general simplicity of the material outlined. The structure of the manual consisted of sections devoted to the parts of machines servicing the rotary movement, gears, special parts. The author considered the problems of studying the physical principles of parts implemented in the construction, outlined the theoretical foundations of design and their mathematical description, considered the causes of damage and failures in the work of machines. The abstract contained a large amount of background information, which greatly increased its value in the absence of reference literature, but needed to deepen and clearer structuring of the material outlined, updating and supplementing information on new developments in the fields of mechanical engineering: gear and pass transmissions, reducers, continued shafts actively develop and develop science in the 20 -es of the twentieth century.

The tumultuous work during the next two years after the publication of the abstract of lectures, testing work with students, correcting deficiencies, and supplementing it, made it possible for V. O. Dobrovolsky in 1928 to turn the abstract in a glass copy into a full textbook for high school, published in Ukrainian (Dobrovol'skij, 1928a). Taking into account that in the technical universities in the 1920-es the courses of the theory of mechanisms, the resistance of materials and parts of machines were highlighted in separate disciplines, the author greatly limited the presentation of theoretical questions, focusing on practical problems of mechanical engineering. The textbook consisted of four sections: parts for connecting machine parts, parts for serving circular motion, transmission and special details (Dobrovol'skij, 1928a, p. 515). This structure of the submission of material confirmed the approach of V. O. Dobrovolsky to the construction of the program studying the course "Parts of Machines", because despite the introduction of corrections in subsequent editions, retained the main model for almost the entire second half of the twentieth century. The introductory part of the manual related to the author's explanation of the term "machine" for its meaning, types, and general requirements (Dobrovol'skij, 1928a, p. 5). Revealing these concepts, the researcher analyzed the views of many foreign authors, but did not mark the achievement of K. Marx, whose "question about the car is considered the most accurate" (Dobrovol'skij, 1932, p. 5), which was considered a disadvantage for contemporary Soviet historiography and was reasonably taken into account in subsequent editions.

At the end of each section, a list of sources was provided, mainly by foreign scholars, for which the author was criticized for the excessive exaltation of "bourgeois science." Despite the large volume of the manual that exceeded five 
hundred pages, there were still no sections devoted to gear and worm gears, variators, factors affecting the strength of parts, standards in mechanical engineering, characteristic of future editions. The manual "Parts of Machines" immediately won the adherence and recognition in scientific circles as one of the best in the country. Contributing to this was the publication in 1928 by Victor Opanasovich of a collection of numerical examples with the solutions, tables and formulas "Calculations of machine parts" (Dobrovol'skij, 1928b), which generally includes seven editions oriented to students and designers without university education, for developing calculating and design skills, which, as the researcher considered, was the basic element in the preparation of a design engineer.

The work of V. O. Dobrovolsky with his original textbook was threatened with termination in 1929, when he, as chief engineer, was arrested on fabricated allegations, but due to the family's request, the leadership of the university, and the fact that during his absence reading the course "Parts of Machines" in the OPI was suspended, the charge was lifted, and the scientist justified (Gusarev, 2015, p. 20).

The second edition of the textbook "Machine Details" was held in 1932 and was partially redesigned, especially with regard to the introductory part and the supplementary version of 1928 . While fully preserving the previous structure, the author adjusted the material in accordance with the program of studying students at the university and reduced the number of examples where Norms and calculations were given that depart from the original mathematical model during the design process. The sections on gearboxes, gear transmissions, information on passive transmissions and the disadvantages of their theory, due to the current discussions in the USSR on the rational efficiency of passes, have increased with new information. Of particular value in the textbook were the parts of the gear, worm, passive transmissions, variators, which were considered by the researcher in their own scientific researches, on the eve of the publication of the textbook, the same goes for the section on welding, the new methods of which were also in the sphere of interests of Viktor Opanasovich. In the chapters of the textbook there appeared a large number of new general standards and norms, the issue of the test of metal rupture, as the main one, was critically examined, since, according to V. O. Dobrovolsky, it did not determine the fragility, wear, elasticity of the material, and pointed to the need to determine the permissible voltage, as the boundaries of elasticity (Dobrovol'skij, 1928a, p. 9). In the sections devoted to wedges, screws and other "simple machines", the scientist noted that such a definition in the literature is false and that all such mechanisms, which consist of one component, should be considered as parts of machines (Dobrovol'skij, 1928a, p. 7).

The new page for the discipline "Parts of Machines" was discovered by Viktor Opanasovich in the edition of the next edition of his own textbook in 1938, it was the first publication of the manual in Russian, which in the future will have five reissues (Dobrovol'skij, 1938). The new textbook was mapped according to all the recommendations of the program to the course "Parts of Machines" approved by the Committee on Higher School Affairs and taking into account the resolutions on 
books on the topic "Parts of Machines" published in the newspaper "Technique". Compared to previous releases, in which the author singled out only a few pages of general calculation and design fundamentals in the introduction, the new version of the textbook, the existing three parts: sealing and connection, machine parts, servicing rotary motion and transmission, added another called - general data to calculate and design Principles (Dobrovol'skij, 1938, p. 5). The emergence of a new section was of special significance from the scientific standpoint, based on his own pedagogical experience, he highlighted the critical mistake of most students who perceived the design process in the form of entering numerical data into mathematical formulas, while the textbook translated this process into an applied field and technological, emphasizing the variability, requirements, and conventionality in the design. From the third edition, V. O. Dobrovolsky adheres to the principle of filling material: initially the theoretical basis, then, on its basis, the construction and methods of their calculations, combined with examples and illustrations, in contrast to the first two parts, where the theoretical part was submitted limited. This approach allowed students to understand the general principles of design and to solve the exercises and tasks that followed the course.

In the first section, for the first time, information was presented separately on the voltage in the machine parts (Dobrovol'skij, 1938, p. 24), factors influencing the part (temperature, friction, operational heating) (Dobrovol'skij, 1938, p. 45), shape of parts and their division (Dobrovol'skij, 1938, p. 49), normal. In the section devoted to fastening and welding, the information has considerably expanded, a part devoted to riveting has appeared (Dobrovol'skij, 1938, p. 74), welding (Dobrovol'skij, 1938, p. 111), bolted connection (Dobrovol'skij, 1938, p. 144). V. O. Dobrovolsky introduced a part devoted to such detail as a wedge key (Dobrovol'skij, 1938, p. 199), for example, he showed how mathematical research can draw conclusions and data for design. In the section "Axes and shafts", a great deal of new information was provided on the classification of shafts, material science issues, calculations of strength, based on personal research by Victor Opanasovich and his student, who studied the shafts, L. B. Ehrlich. There was a separate item devoted to bearings (Dobrovol'skij, 1938, p. 371) in the section "Details Serving the rotary motion" is largely based on the original research of the scientist and the department "Parts of Machines" OPI, especially as it relates to the part dedicated to special bearings, where the bearing "Nomy" was considered, in relation to which the researcher published an article in the Journal of Mechanical Engineering (Dobrovol'skij, 1929), and the paragraph "Needle bearings", the development of which was one of the first on the threshing floor of the USSR department under the leadership of Viktor Opanasovich, and marked the publication of a number of articles during the 30-es of the XX-th century and the monograph "The Eagle Bearing" in 1935 (Dobrovol'skij, Podderegin $\&$ Podderegin, 1935). The point about the transfer did not pass the addition and reformatting, which also constituted the sphere of scientific interests of the scientist. The section is devoted to passports, received a solid foundation in the form of a 
separate monograph "Pass transmission" in 1934 (Dobrovol'skij, 1936a), and a globose worm gear in the article 1936 (Dobrovol'skij, 1936b).

Regarding the general trends of the textbook, the author reduced the number of deductions, examples and tasks so as not to overload the textbook, since the presentation of the course was conducted in parallel with the use of special collections of tasks and machine parts designs, which were also developed and continuously refined and published by scientists in 1933, 1934, 1935, 1936.

The next edition of the 1939 textbook (Dobrovol'skij, 1939) was an almost complete copy of the previous one with only a few minor additions and corrections. The two pre-war editions of the 1938 and 1939 book were a reflection of the researcher's new vision of the subject "Parts of Machines", taking into account the latest scientific advances and recommendations in various fields of engineering multiplied by twenty years of teaching the course and almost thirty as a designer and engineer, contributed to the emergence of the most complete a textbook on discipline on the thorns of the entire USSR.

The end of the Second World War marked the return of Viktor Opanasovich to his teaching activities as a main activity and continued his work on improving his own textbook. In 1945 the third Russian edition of the manual "Parts of Machines" was published (Dobrovol'skij, 1945). The basis of the work, as before, consisted of personal studies and research work of the scientist, as well as materials provided by his students who had already completed or continued postgraduate studies, including: L. B. Ehrlich, S. L. Mak., K. I. Zablonsky and the staff of the department "Parts of Machines". The structure of the textbook has not changed much compared to the previous editors, but received a number of new additions aimed at improving the study of material, has been significantly expanded and reached a record eight hundred and fifteen pages. Such an increase in the amount of material submitted was due to the presentation in the manual of a large number of calculations for design, which required an updated program for the course "Parts of Machines", which were previously placed by the author in a separate edition of "Calculations to machine parts," but fully contain all the necessary material, even in this volume it was not possible, therefore in future editions the calculation material will be reduced.

Again, the first section was corrected, in which a small retreat appeared on the requirements for the parts of machines (Dobrovol'skij, 1945, p. 6), in order to comply with the latest technical requirements and designation. In order to improve students' learning of the variability that arises during the design process, due to different properties of materials, V. O. Dobrovolsky reformatted a number of sub-points that provided important theoretical information. Part of the "voltage in the machine parts," was supplemented with information about the load and turned into a "Classification of Voltages and Load" (Dobrovol'skij, 1945, p. 9), the section on the factors affecting the resistance of the parts has increased considerably, with the advent of information on decrement, surface condition, absolute dimensions that were absent in the past edition. There were new sub-items devoted to the characterization of mechanical properties of materials (Dobrovol'skij, 1945, p. 12), theory and definition of durable 
stocks (Dobrovol'skij, 1945, p. 33). With the introduction of these changes, the section "General information, some data for calculations and the basis of design" turned into a solid theoretical basis for students when familiar with the design features and their differences compared with mathematical calculations.

The second section also changed, where the researcher provided information on new types of welds and a section devoted to the details of welded products (ribs, flanges, levers) (Dobrovol'skij, 1945, p. 172), which supplemented previously verified information. In the part devoted to "Parts servicing the rotary motion", the points of "rolling resistance friction" with "special bearings" were merged and a new section on "safety couplings" was added (Dobrovol'skij, 1945, p. 501).

The largest modification and additions were to the section on the transfer, which has increased from two hundred to three hundred pages. The review of tooth gears has considerably expanded, due to the great attention to this issue, the Department of Machine Parts, OPI on the eve of the war, and especially with the studies of the postgraduate student V. O. Dobrovolsky - K. I. Zablonsky. In the context of the development of research in the field of worm gears, the researcher greatly supplemented the material devoted to them, a section on the details of these programs appeared, aimed at improving the understanding of their design and work. Also, for the first time separately presented friction-gear variators of planetary type (Dobrovol'skij, 1945, p. 806) and pulsed variators (Dobrovol'skij, 1945, p. 808), which only began to be actively explored and used in the second half of the twentieth century.

The textbook of 1945 edition became the largest and most complete summary of information on the discipline "Parts of Machines" in the USSR (Zablonskij, 1998, p. 170). The material presented in it was tested on a multitude of classes with students, at the same time, differed in its own novelty. The textbook took a prominent place in the development of the discipline, but later, V. O. Dobrovolsky returned to an earlier method of material presentation and reduced the excessively voluminous parts with calculations and tasks.

The progressive evolution of science caused the scientist to update the manual. In 1951, the publication of the sixth edition of the "Parts of Machines" (Dobrovol'skij, 1951), which was an updated and updated version of 1945. Following the course "Parts of Machines" for universities, within the scope of the material, compared with the previous publications, the structure of the textbook has changed, to the more modern, which has become the basis for all further manuals of the author and his students, and also is the basic and for most modern manuals on the course "Parts of Machines". Changing priorities in the preparation of designers, led to increased priorities of transmissions, the importance of studying their designs, in the process of training designers and engineers has increased significantly, and in the textbook they took the third chapter (Dobrovol'skij, 1951, p. 300), and the parts serving the rotational motion, respectively, became the fourth (Dobrovol'skij, 1951, p. 555). In addition to the new structure of the sixth edition, the main innovations concerned a slight reduction in the calculation material (formulas, tasks, figures, 
schemes) and the overall update of the information presented in accordance with new standards and norms implemented in the country and achievements in various fields of engineering.

The last personal edition of V. O. Dobrovolsky's textbook "Parts of Machines" was held in 1954 (Dobrovol'skij, 1954). Understanding the inability to contain, even in the old record volume of the basis of the theory and methods of calculating the parts of machines at the same time with materials for calculation and design, including the formula formulas, standards and norms, Victor Opanasovich radically reduced the volume of the textbook. The sections devoted to the rivets and bolted joints, which was associated with the gradual replacement of the latest welding, significantly decreased. The section on transmissions updated and supplemented with information, especially concerning teeth gear transmissions, the research of which actively developed during this period, including the employees of the department "Parts of Machines" OPI. In a separate division there was a "Cutting of gear wheels with a straight teeth" (Dobrovol'skij, 1954, p. 246), there were data on new types of couplings and methods for their calculation (Dobrovol'skij, 1954, p. 553), the material on the shafts expanded, which made it possible to significantly update the third section, "Details Serving the rotary movement", respectively, on the new achievements of science and technology.

The seventh edition laid the foundations for further development and development of the textbook as the basis for the preparation of students, unlike the previous parts, which were simultaneously being prepared as reference books for designers. It is this approach that will be implemented in the next seven editions, the collective of the authors of the department "Parts of Machines" OPI together with V. O. Dobrovolsky, which will be published during 1956-1972 (Gnatjuk, Islamgulova \& Jakovleva, 2008, p. 12).

\section{Conclusions}

Personal experiences of Viktor Opanasovich in preparing his own textbook are amazing in their scope. For almost 25 years, the author independently worked out, prepared, systematized and tested the information he collected, constantly reflexing and trying to supplement and improve it. The work of the scientist in various directions of mechanical engineering and the perspective and original research conducted at the department under his leadership, combined with enormous pedagogical and practical experience, gave him the opportunity to develop an accessible and understandable textbook that responded to the challenges of time and could be used as students during training, as designers during work. Thanks to the constant work of the scientist, in the conditions of almost complete lack of educational literature in the late 20 -es of the twentieth century the country received the first fullest collection of materials on discipline, which gave the opportunity to prepare thousands of engineering and design personnel. Further editions of the textbook only increased its value for higher technical education, and its use has become an all-Union nature. Much of the recommendations for the calculations and 
design of gears and parts of machines, presented in books by Victor Opanasovich, are still used.

Emphasizing the value of the manual for the development of science, it is important to note that the works of V. O. Dobrovolsky were crucial for the establishment of the discipline "Parts of Machines" in the first half of the twentieth century, and together with the collection "Calculations of machine parts" actually formed the basis of its teaching in higher technical educational institutions of Ukraine and the USSR during this period.

\section{References}

The personal cases of OPI employees. D. Archive ONPU [Odessa National Polytechnic University]. F. R-126. Op. 11. 250. [in Ukrainian].

Dobrovol's'kij, V.O. (1928a). Detali mashin: yihnja teorija, konstrukcija ta rozrahunok [Machine parts: their theory, design and calculation]. Odesa: Mashbudvidav [in Ukrainian].

Dobrovol'skij, V. A. (1928b). Primernye raschety detalej mashin. Posobie dlja konstruktorov [Approximate calculations of machine parts. Handbook for designers]. Odessa: Odespoligraf [in Russian].

Dobrovol's'kij, V. O. (1929). Pidshipnik «Nomy» [Bearing "Nomy"]. Vestn. Metallopromyshlennosti - Electrotechnical Herald, 2, 21-27 [in Russian].

Dobrovol's'kij, V. O. (1932). Detali mashyn: yikhnia teoriia, konstruktsiia ta rozrakhunok [Machine parts: their theory, design and calculation]. Odesa: Mashbudvidav [in Ukrainian].

Dobrovol'skij, V. A. (1936a). Sovremennye parovye avtomobili i traktory [Modern steam cars and tractors]. Kharkiv: Gostehizdat Ukrainy [in Russian].

Dobrovol's'kij, V. A. (1936b). Globoidnaja chervjachnaja peredacha [Globoid worm gear]. Vestn. Metallopromyshlennosti - Electrotechnical Herald, 10, 27-39 [in Russian].

Dobrovol'skij, V. A. (1938). Detali mashin. Teorija, konstrukcija i raschjoty: ucheb. dlja mashinostroit. Vtuzov [Machine parts. Theory, design and calculations: studies. for machine building. technical colleges]. Moscow: Mashgiz [in Russian].

Dobrovol'skij, V. A. (1939). Detali mashin. Teorija, konstrukcija i raschjoty: ucheb. dlja mashinostroit [Machine parts. Theory, design and calculations: studies. for machine building. technical colleges]. Moscow: Mashgiz [in Russian].

Dobrovol'skij, V. A. (1945). Detali mashin. Teorija, konstrukcija i raschety: ucheb. posobie dlja mashinostroit [Machine parts. Theory, design and calculations: studies. for machine building. technical colleges]. Moscow: Mashgiz [in Russian].

Dobrovol'skij, V.A. (1951). Detali mashin: ucheb. posobie dlja vtuzov USSR [Machine parts: studies. manual for colleges of Ukraine]. Kharkiv: Gostehizdat USSR [in Russian]. 
Dobrovol'skij, V.A. (1954). Detali mashin: ucheb. posobie dlja vtuzov USSR [Machine parts: studies. manual for colleges of Ukraine]. Kiev: Gostehizdat USSR [in Russian].

Dobrovol'skij, V. A., Podderegin, D.M., \& Podderegin, V.M. (1935). Igol'chatye podshipniki: Konstrukcija, raschety, proizvodstvo, montazh $i$ uhod [Needle bearings: Design, calculations, production, installation and maintenance]. Odessa: Chernomorskaja kommuna [in Russian].

Professor Har'kovskogo Tehnologichesskogo instituta Vadim Jerastovich Tir [Professor of the Kharkov Technological Institute Vadim Erastovich Tir]. (1926). Elektrotekhnicheskij vestnik - Electrotechnical Herald, 3-4, 44-47 [in Russian].

Gnatjuk, T. J., Islamgulova, Z. H., \& Jakovleva, I. A. (2004). Viktor Opanasovich Dobrovol's'kij. Bibliografichnij pokazhchik [Viktor Opanasovych Dobrovolsky. Bibliographic index]. Odesa: Nauka i tehnika [in Ukrainian].

Gusarev, V.S. (2015). Viktor Afanas'evich Dobrol'skij Inzhener pedagog uchitel' [Victor Afanasyevich Dobolsky Engineer educator teacher]. Odessa [in Russian].

Ivanov M. N., \& Finogenov V. A. (2008). Detali mashin [Machine parts]. Moscow: Vysshaja shkola [in Russian].

Zablonskij, K. I. (1998). Odesskaja nauchnaja shkola v stanovlenii i razvitii kursa detalej mashin kak sostavnoj chasti mashinovedenija [Odessa Scientific School in the formation and development of the course of machine parts as an integral part of engineering]. Tr. Odes. politehn. un-ta.- Works of Odessa Polytechnic University, 1(5), 168-174 [in Russian].

\section{Бандус Вячеслав Олексійович}

Одеський національний політехнічний університет

1, пр. Шевченка, м. Одеса, Україна, 65044

\section{Підручник «Деталі машин» В. О. Добровольського та його значення для розвитку вищої технічної освіти в Україні}

Анотація. В статті розглянуто діяльність видатного українського науковия, доктора технічних наук, професора Одеського політехнічного інституту Віктора Опанасовича Добровольського з підготовки семи редакиій підручника "Деталі машин». На сучасному етапі розвитку історії науки $i$ техніки, комплексний аналіз наукової діяльності В. О. Добровольського, в галузі загального машинобудування, в цілому представлений вкрай обмежено, а висвітлення його ролі в організації та розвитку вищої технічної освіти в Україні, майже відсутне. Вчений, одним із перших розпочав роботу над проблемою відсутності повноиінного посібника з дисиипліни «Деталі машин» для вищої школи, розробкою $і$ удосконаленням якого, він продовжував займатися на протязі усієї власної діяльності в Одеському політехнічному 
інституті. Проаналізовано еволюиію підручника, починаючи з публікації В. О. Добровольським у 1926 р. першого видання «Конспекту до курсу «Деталі машин»» до останнього, сьомого, особистого видання «Деталі машин» 1954 р. Встановлено основні напрямки та пріоритети, що виділялись вченим, $у$ кожному із семи видань для підготовки студентів $i$ конструкторів та розглянуто доцільність їх визначення в контексті розвитку машинобудування 3 точки зору історичної ретроспективи. Коротко охарактеризовано роль особистих досліджень, винаходів, розробок науковия та його колег і учнів, в підготовиі матеріалів підручника, відповідність наведеної інформаиіі програмам курсів, та змінам, щзо вносились вченим до видань різних років, задля відповідності завданням програм та різного роду рекомендаціям, щзо надходили від Міністерства освіти та великого кола науковців, з якими співпрачював Віктор Опанасович. Особливу увагу приділено відповідності підручників сучасним для них досягненням науки і техніки, та постійну увагу вченого до нових вітчизняних та зарубіжних розробок та винаходів. Порівняно структуру посібників та встановлено причини скорочень, доповнень і появи нових розділів, y відповідності до завдань, що стояли перед В. О. Добровольським у різні періоди його діяльності. Наголошено на великій популярності та широкому використанні підручника більшістю вищих технічних закладів на просторах усього СРСР, щзо було наслідком загальної доступності та глибокого опрацювання викладеного теоретичного $i$ практичного матеріалу, його актуальності і відповідності викликам часу.

Ключові слова: В.О.Добровольський; професор; ОПІ; загальне машинобудування; передача

\section{Бандус Вячеслав Алексеевич}

Одесский национальный политехнический университет

1, пр. Шевченка, г. Одесса, Украина, 65044

\section{Учебник «Детали машин» В. А. Добровольского и его значение для развития высшего технического образования в Украине}

Аннотация. В статье рассмотрена деятельность известного украинского исследователя, доктора технических наук, профессора Одесского политехнического института Виктора Афанасьевича Добровольского по подготовке семи редакиий учебника "Детали машин». На современном этапе развития истории науки и техники, комплексный анализ научной деятельности В.А. Добровольского, в сфере общего машиностроения, представлен крайне ограничено, а освещение его роли в организачии и развитии высшего технического образования в Украине, практически отсутствует. Ученьй, одним из первых отреагировал на отсутствие полноченного пособия по дисииплине «Детали машин» для высшей школь и посвятил решению данного вопроса большую часть своей работь в Одесском политехническом 
институте. Проанализирована эволюичя учебника, начиная с публикации ученым в 1926 г. первого издания «Конспекта к курсу "Детали машин»» до последнего, седьмого, личного издания "Деталей машин» 1954 г. Установлень основные направления и приоритеты, которые выделялись исследователем в каждом из изданий для подготовки студентов $u$ конструкторов $u$ рассмотрено целесообразность их определения с точки зрения исторической ретроспективы. Кратко характеризировано место личных научных достижений, наработок, изобретений В. А. Добровольского и его коллег $u$ учеников, в подготовке материалов учебника, соответствие приведенной информации программам курсов и изменениям, вносимым ученым в издания различных годов, для соответствия задачам программ и разного рода рекомендациям, поступавших от Министерства образования и широкого кола ученых, с которыми сотрудничал Виктор Афанасьевич. Особое внимание уделено соответствию учебников современным для них достижениям науки $и$ техники, $u$ постоянное внимание ученого $\kappa$ новым отечественным $u$ зарубежныл разработкам и изобретениям. Установлень обшие черты $u$ различия в структуре пособий, причины сокращений, дополнений и появления новых разделов, в соответствии с задачами, которые стояли перед B. А. Добровольским в разные периоды его деятельности. Отмечена большая популярность и иирокое использование учебника больиинством высиих технических заведений на территории всего СССР, что являлось следствием общей доступности и глубокой проработки изложенного теоретического $и$ практического материала, его актуальность и соответствии вызовам времени.

Ключевые слова: В.А.Добровольский; профессор; ОПИ; общее мачиностроение; передача

Received 21.01.2019

Received in revised form 05.04.2019

Accepted 14.04.2019 